\title{
British migrants and Irish anxieties
}

\author{
Mary Gilmartin* \\ Department of Geography, National University of Ireland, Maynooth, Ireland
}

(Received 25 August 2011; accepted 24 September 2012)

\begin{abstract}
There is a long history of migration from Britain to Ireland, but it is rarely theorised as migration. Drawing on historical and contemporary sources as well as ongoing qualitative research, this paper makes visible the extended presence of British nationals, as migrants, in Ireland. In discussing the conflicted geographies of belonging of recent British migrants to Ireland, the paper highlights the ways in which postcolonial and nationalist discourses may suggest boundaries to belonging. However, these boundaries are undermined by the positioning of British migrants as not-quite-migrants in the changing landscape of migration in contemporary Ireland.
\end{abstract}

Keywords: migration; Ireland; Britain; postcolonial theory

\section{Introduction}

Two of the central characters in John McGahern's last novel, That They May Face the Rising Sun, are Joe and Kate Ruttledge, who had migrated to Leitrim from London many years before the novel opens. Joe had grown up among the 'rushy fields, the poverty, the hardship' of Leitrim (McGahern, 2002, p. 19). He had escaped through education, but he chose to return, with his English wife Kate, just as others were escaping in the opposite direction. When they first arrived, they were 'shunned by near neighbours' (McGahern, 2002, p. 21), but over time they became a respected and valued, if slightly separate, part of the rural community. When their neighbour Jamesie's brother threatened to return home from England, it was to the Ruttledges he turned for support and help. Yet, when the Ruttledges' English friends came to visit, Jamesie stayed away. 'The robins don't mix with the blackbirds', they were told (McGahern, 2002, p. 157).

McGahern's novel is firmly set in place - a rural community in the west of Ireland but the ongoing movement of people into and out of that place is one of its key subtexts. His use of Joe and Kate Ruttledge as central characters in the novel points to an important, if under-researched, aspect of mobility in contemporary Ireland: that of migration from Britain to Ireland. ${ }^{1}$ Nationals of Britain have been free to travel to, live and work in Ireland without restrictions for decades, because of an arrangement known as the common travel area (Ryan, 2001). While this right has now been extended to all European Union (EU) nationals, British nationals in Ireland have additional privileges, such as greater access to political participation than other nationals, a greater likelihood of unproblematic recognition of education, training and experience, and a shared language and (some) cultural traditions. The ease of movement between Britain and Ireland,

*Email: Mary.Gilmartin@nuim.ie 
together with the apparent lack of obstacles to the integration of British nationals in Ireland, mean that British nationals living in Ireland are rarely described as international migrants. Instead, discussions of international migration to Ireland are more likely to focus on migrants from other EU states, or from outside the EU. Yet, it is also inaccurate to describe British nationals in Ireland as internal migrants, since movement between the two countries involves crossing an international border, albeit a disputed one, and British nationals in Ireland have fewer rights and entitlements than Irish nationals. ${ }^{2}$ The status of British nationals living in Ireland is, therefore, quite ambiguous. There is a corresponding ambiguity in the often hidden story of Irish nationals in Britain (Dunne, 2003; Mac an Ghaill, 2000).

This paper takes the story of migration from Britain to Ireland as its starting point, and uses it as the basis for a broader discussion of belonging in contemporary Ireland. Following a general discussion of migration from Britain and to Ireland, it draws on recent qualitative research with a small group of British nationals who moved to Ireland in either 2004 or 2007. Their accounts of belonging and non-belonging in Ireland highlight the contingent and contested nature of both British and Irish identities, a point that is explored in more detail in the context of postcolonial and nationalist discourses. The paper concludes with a reflection on the complicated relationship between migration and identity, a relationship that is coming under increased scrutiny in the context of contemporary Ireland.

\section{Migration from Britain}

Seen from a British perspective, That They May Face The Rising Sun makes visible the complicated patterns of movement of people from Britain to Ireland and elsewhere. In 2006, the UK's Institute for Public Policy Research estimated that there were around six million Britons living overseas: Australia was the top destination, followed by Spain, the US, Canada and Ireland (Table 1).

The IPPR claim that in all but one year of the last 40, there was net emigration of British nationals from the UK, and that around one in ten Britons live overseas. There are differences in the demographic profiles of Britons in the top destination countries.

Table 1. Estimates of British people living outside Britain.

\begin{tabular}{lc}
\hline Country & Number of British residents (full and part time) ('000s) \\
\hline Australia & 1,310 \\
Spain & 990 \\
United States & 685 \\
Canada & 609 \\
Ireland & 320 \\
New Zealand & 217 \\
South Africa & 214 \\
France & 261 \\
Germany & 127 \\
Cyprus & 65 \\
Other countries & 1,251 \\
Total & 6,050 \\
\hline
\end{tabular}

Source: Sriskandarajah and Drew (2006, p. 17). 
Australia, Spain, the US and Canada all have older British populations than Ireland, yet there are over 100,000 people living in Ireland who are in receipt of UK state pensions (Sriskandarajah \& Drew, 2006, p. 28). As elsewhere, the reasons for migration are varied, but the IPPR suggest four key reasons: family ties, lifestyle, overseas adventure and work (Sriskandarajah \& Drew, 2006, p. 38).

Despite the obvious importance of emigration as a social process in Britain, there is limited academic literature on the topic, with some exceptions. There is a growing body of work on retirement migration and lifestyle migration (Benson, 2010; King, Warnes, Warnes \& Williams, 2000; Oliver, 2008; Oliver \& O'Reilly, 2010; O'Reilly, 2000), student migration (Findlay, King, Stam \& Ruiz-Gelices, 2006; King \& Ruiz-Gelices, 2003) and return migration from Britain (Phillips \& Potter, 2009; Potter \& Phillips, 2009). There is also a small body of work on elite migration: on the transnational elites who populate the global cities so beloved of urban studies (Beaverstock, 2002, 2005; Scott, 2006; Yeoh \& Willis, 2005), while a recent focus on 'postcolonial migration' includes work on British migration to former colonies such as Hong Kong and Dubai (Coles \& Walsh, 2010; Leonard, 2010). However, the overwhelming sense is of Britain as a place people immigrate to rather than emigrate from. The IPPR's 2006 report is the only comprehensive overview of emigration from Britain in all its generality, yet it provides little analysis of why emigration from Britain receives limited academic or policy attention. One comment in the report provides some enlightenment: 'a Briton moving abroad is seen as part of the natural order of things' (Sriskandarajah \& Drew, 2006, p. 91).

\section{British migration to Ireland}

According to this way of thinking, Britons in Ireland are also part 'of the natural order of things'. The extent of British migration to Ireland has been documented in a variety of ways although, interestingly, rarely as 'migration'. For generations, British people have been the most significant migrant group in Ireland. In the period prior to Irish independence, when Ireland was part of the United Kingdom, there was regular movement of people between Britain and Ireland in a form of 'internal migration'. For example, in 1881, there were just over 91,000 people from England, Scotland and Wales living in Ireland. Ernest Ravenstein, whose laws of migration (1885) were the first systematic attempt to systematise seemingly lawless migration patterns, based his analysis on a detailed study of this internal migration between and within Britain and Ireland. He used the term 'floating population' to describe the British presence in Ireland in 1881 . Soldiers and sailors made up over 20 per cent of those 91,000, and they were concentrated in Dublin and Kildare in particular. The Irish National Archives, in their commentary on the 1911 Census, also draw attention to the military presence, but additionally highlight other British migrants - colonial administrators, professional and business people, and skilled manual labourers - who had also made Ireland their home (National Archives of Ireland, n.d.). In other words, while the nature of the colonial relationship facilitated some of the migration between Britain and Ireland, it is not sufficient to explain all migration. Immediately after independence, these numbers dropped. In the 1926, 1936 and 1946 Censuses, just under 50,000 people recorded their place of birth as England, Scotland or Wales (Central Statistics Office, 1952). While this may be partially explained by independence, it also reflects a sharp decline in general levels of emigration from Britain in the inter-war period (Sriskandarajah \& Drew, 2006, p. 12). By 1961 , the numbers began to rise again, and by 1986 , over 140,000 people 
living in Ireland were born in Britain (Central Statistics Office, 1993). Though many of these were of Irish nationality, their presence suggests an ongoing movement of people between Ireland and Britain. Geographer Catherine Nash's description of her own ancestral history illustrates the complexity of this relationship over generations:

at least three generations of 'mixed marriages' and the religious conversions they entailed on both sides of my family, the patterns of migration that led to family members' births in England and lives in Ireland, and births in Ireland and lives in England. (Nash, 2008, pp. ix-x)

In each of the three most recent Censuses, over 100,000 people have reported UK nationality. The 2002 Census recorded 103,426 people of UK nationality in Ireland, and by 2006 and 2011, this number was over 112,000 (Central Statistics Office, 2003, 2007, 2012). In 2006, just as in 1881, Ireland's largest migrant community came from the country's nearest neighbour, even though the nature of that migration had changed from 'internal' to 'international' (King \& Skeldon, 2010). ${ }^{3}$

Despite the ongoing and substantial presence of British nationals in Ireland, knowledge of their motivations and experiences is limited. There has been a tendency to explain British migration in general through a colonial framework: British migrants were 'effectively internal migrants within the empire' (Fitzgerald \& Lambkin, 2008, p. 257). As such, Fitzgerald and Lambkin suggest that British migrants to Ireland during the 1800s fell into five main categories: civil servants, soldiers, land agents, churchmen and tourists (Fitzgerald \& Lambkin, 2008, p. 150). They also hint at the presence of other migrants, such as skilled labourers working in Belfast, but make limited reference to the possibility of migration for reasons other than imperial usefulness. Indeed, their survey of migration to Ireland in the period from 1950 to 2007 has no recognition of British migration: it is as if British migration to Ireland ended at the point of independence.

\section{British migrants in Ireland}

Yet, British migration to Ireland continues, and the 2006 Census paints the best contemporary picture of this group of migrants. According to that Census, over 112,000 people living in Ireland reported UK nationality, while a further 14,829 reported joint Irish-English nationality (Central Statistics Office, 2007). The question on nationality is self-reported: respondents are asked to identify their nationality, and their responses are then coded by the Central Statistics Office (CSO). A second insight is provided by the identification of place of birth. Just over 220,000 people living in Ireland in April 2006 were born in England, Wales or Scotland, while a further 50,000 were born in Northern Ireland (Central Statistics Office, 2007). The significant difference between nationality and place of birth may be explained in a variety of ways: for example, by people who have become naturalised in Ireland, or by people born in the UK who have other nationalities. However, to a large extent the difference is accounted for by people of Irish descent born in the UK who understand their nationality as Irish (see Table 2).

From the 2006 Census, it is also possible to identify the differences between UK and other migrant groups living in Ireland. The profile of UK nationals in Ireland is of a slightly older group than other migrant groups, with almost one in six retired (Central Statistics Office, 2008, p. 25). In terms of employment, education, social class and household composition, the experiences of UK nationals in Ireland mostly closely 
Table 2. Selected nationality and country of birth of residents of Ireland, 2006.

\begin{tabular}{rrrrrrr}
\hline & & \multicolumn{5}{c}{ Country of birth } \\
\cline { 3 - 7 } Nationality & \multicolumn{1}{c}{ Total } & Ireland & $\begin{array}{c}\text { Northern } \\
\text { Ireland }\end{array}$ & $\begin{array}{c}\text { England and } \\
\text { Wales }\end{array}$ & Scotland & $\begin{array}{c}\text { Other/not } \\
\text { stated }\end{array}$ \\
\hline Irish & $3,661,560$ & $3,488,778$ & 45,601 & 98,118 & 4,857 & 24,206 \\
Irish-English & 14,829 & 2,224 & 1,135 & 10,432 & 728 & 310 \\
UK & 112,548 & 2,701 & 2,847 & 91,811 & 10,930 & 4,259 \\
\hline
\end{tabular}

Source: Central Statistics Office, 2007, Table 37.

resemble that of Irish nationals. However, UK nationals are more likely to live in rural areas (Gilmartin \& Mills, 2008), more likely to own their own houses, and more likely to live in mixed-nationality households with people of Irish nationality than other migrant groups (Central Statistics Office, 2008) - the robins mixing with the blackbirds, after all. The CSO report, for the first time, highlights the demographic profile of migrants to Ireland from the UK. Beyond this, however, we know very little about their experiences as migrants. People from the UK, living in Ireland, are rarely considered as migrants: as journalist Shane Hegarty comments, "when we talk about "the new Irish", there's a clear sense that we're not including the Brits in that mix' (Hegarty, 2007). In the growing body of academic research on migration to Ireland, migrants from the UK receive limited attention (Gilmartin \& White, 2008, p. 147).

The discussion that follows draws on a broader research project that focused on the experiences of recent migrants to Ireland. The project ran from 2008 to 2011, and focused on two recent migrant cohorts - people who moved to Ireland in either 2004 or 2007. Participants thus had spent between one and five years in Ireland before their first involvement in the project. We also used a longitudinal approach to our research, which meant that we interviewed participants twice over the course of the project. In total, 60 people participated in the project, 11 of whom identified as British. ${ }^{4}$ Mindful of the limited knowledge about migrants from Britain in Ireland, we actively sought out British people to participate in the research, and we recruited participants using personal contacts, snowballing, fliers and online discussion groups. The first interviews were semistructured, and focused on topics such as motivations for migration, migration history, work, neighbourhood, identity and experiences of living in Ireland. However, the second were unstructured and related to the specific experiences of the participant as told to us previously. The interviews were recorded and transcribed, and analysed through the identification of key themes (see Gilmartin \& Migge, 2013; Migge \& Gilmartin, 2011, 2013 for other thematic analyses of this data). While the number of interviewees is small (11 in total; six men and five women), they cover a range of ages, locations, and backgrounds, with a varied range of reasons for moving to Ireland (see Table 3). ${ }^{5}$ The in-depth qualitative method provided important insights into their experiences as migrants. In this way, their stories speak to the ambivalent position of British people in Ireland, and I want to highlight that ambivalence through the ways in which these interviewees discuss the geographies of belonging in their new homes.

\section{Geographies of belonging}

Geographers discuss belonging at a range of different scales, from the home (Ralph \& Staeheli, 2011) and the materiality of 'home-making' (see, for example, Tolia-Kelly, 
Table 3. Research participants, selected characteristics.

\begin{tabular}{llrcll}
\hline Identifier & Gender & Age & Location & Primary reason for moving & $\begin{array}{c}\text { Self-identified as } \\
\text { ethnic Irish }\end{array}$ \\
\hline 2004UK01 & M & 35 & Urban - East & Work & No \\
2004UK02 & M & n/a & Urban - East & Relationship & Yes \\
2004UK03 & M & 37 & Urban - East & Work & Yes \\
2004UK04 & F & 41 & Rural - South & Work & No \\
2004UK05 & F & 34 & Urban - East & Relationship & No \\
2004UK06 & F & 67 & Rural - South & Lifestyle & Yes \\
2007UK01 & M & 29 & Urban - East & Work & Yes \\
2007UK02 & F & 42 & Urban - East & Family & No \\
2007UK03 & M & 46 & Urban - South & Work & No \\
2007UK04 & F & 48 & Rural - West & Family & Yes \\
2007UK05 & M & 28 & Rural - West & Work & No \\
\hline
\end{tabular}

2004, 2006) to community formation and development (Merrill, 2006), to the formal scale of belonging afforded by access to citizenship (Ehrkamp \& Leitner, 2006; White \& Gilmartin, 2008). In our interviews, belonging was often described quite differently - in terms of friends, and in terms of feelings or emotions. For those British people who had Irish parents, or who had a strong sense of ethnic connection to Ireland, emotional terms predominated, though often expressed in a tentative way. One man, living in Dublin but with maternal grandparents from Wexford, said 'I had a kind of affinity with the place... I would say I was more Irish than British' (2004UK03). ${ }^{6}$ Another Dublin-based interviewee, whose parents were from the west of Ireland, commented that 'we were always saying that we would like to move over to Ireland' (2007UK01), and that he loved visiting the west when he was younger since 'they wouldn't... see us as... a stranger back there' (2007UK01). In contrast, people who did not identify as ethnically Irish usually highlighted friendships as a way of belonging in place. One woman, who moved to Ireland because of her husband's job, said 'we have put down very strong roots here now and have a really nice network of friends' (2007UK02). A Cork-based interviewee, while unhappy about many aspects of her life in Ireland, said that she really likes the people in Ireland: 'they are so friendly' (2004UK04); a comment echoed by a Scottish man living in Cork who said 'the people are so friendly here' (2007UK03).

The articulation of the similarities between Ireland and Britain was a common theme among interviewees who did not identify as ethnically Irish. The Cork-based woman said that the people 'are quite similar to us' (2004UK04); while the Dublin-based woman spoke about how she and her family now 'go home to Ireland', and that they identify as being from Ireland when outside the country:

I do feel very at home in Ireland

it amazed me how instantly at home I felt here (2007UK02) ${ }^{7}$

One Dublin-based professional was explicit about the ways in which moving to Ireland was quite straightforward for people from England.

I think for English people coming here in some ways it belongs to the same culture the same really you can't deny that 
and so it's really not a big deal.

It's just like

if someone moved

from the south of England

I sort of consider Dublin

as part of the north of England

really. (2004UK01)

Yet, the efforts to create ethnic and emotional senses of belonging were often disrupted by other, competing narratives that highlighted differences. These narratives of difference ranged from the material to the structural; from the emotional to the social. Accents and language were often mentioned - different words (like 'yoke' and 'eejit' (2007UK02) and 'howaya' (2004UK06)), different accents ('they can't say ths but they can when it is not supposed to be there' (2004UK04)), in effect a different language ('they just speak so fast and they jumble all their words together and to tell you the truth I think they have a very limited vocabulary' (2007UK03)). For the Cork-based Scottish interviewee, food had become a problem:

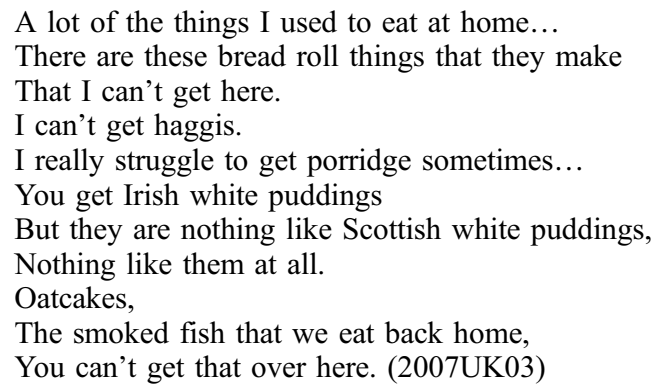

While he was most vocal about food, other anxieties appeared from time to time in the interview. He spoke about the way everything in Ireland revolves around the pub, and about how 'there doesn't seem to be a middle ground here, from one extreme to the other and there is nothing in the middle' (2007UK03). The English woman in Cork, who said she had been 'seriously de-skilled since moving here' (2004UK04), spoke about difficulties in having her qualifications recognised, her failures to get promoted, the culture of bullying and the reluctance of Irish people to complain. In contrast:

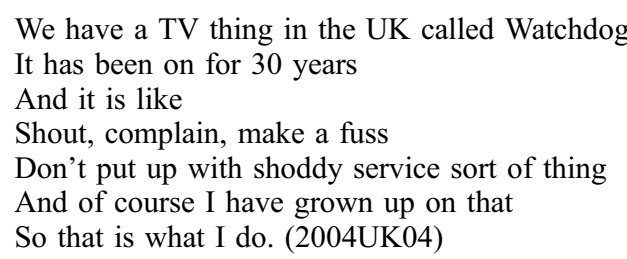

For the Dublin-based woman who felt at home in Ireland, her sense of belonging was framed in terms of difference from England:

and I think

maybe

that has something to do with...

Because I am very talkative

and Irish people are very talkative

and I often felt in England I was too talkative

because I am very open. 
Whereas here everyone seems very talkative,

Especially the neighbours,

They would talk all day

And so would I. (2007UK02)

Yet, for all her attempts to construct a narrative of belonging, other discordant notes regularly appeared. She spoke of the difficulties in making friends with Irish people, who 'have such a full life already that they just don't have room for anybody else' (2007UK02); of the Irish neighbours who would attend her parties but 'wouldn't really ever reciprocate by doing anything' (2007UK02). 'People tend to keep themselves to themselves', a Kildare-based man with an Irish mother commented (2004UK01). Perhaps the most complex insight came from the man living in the west of Ireland who said, 'I think because there are so many similarities, actually maybe that is what took me longer to realise that there so many differences between the two countries' (2007UK05).

Most striking, though, were the interviewees' attempts to make sense of being British in Ireland. An English woman who had moved to the west of Ireland from Canada, with her Irish husband, said:

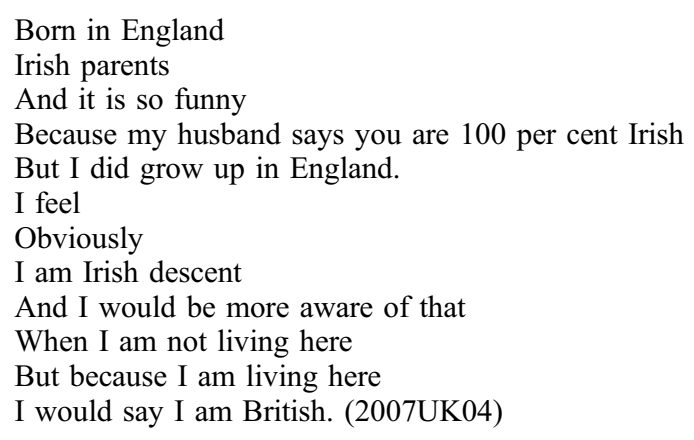

Others spoke of the desire to search out other British or English people:

We can relate to them great

Because they have the same sort of sense of humour as us

And if we are sitting there moaning about Brian Cowen [the Irish Prime Minister] or that

Whereas the locals might get a bit upset

That we are insulting the Irish

We can do that amongst the four of us

Because we understand what we mean. (2004UK04)

However, the English woman in the west of Ireland was one of a number who spoke of a latent anti-Englishness, a situation that has also been documented in Scotland (McIntosh, Sim, \& Robertson, 2004):

There is still that feeling

of some people chatting about the English

and it is quite subtle

but I am quite aware that I am from England

There is that element of, $\mathrm{mmm}$,

She is a Brit...

And a lot of my friends

Who are from England and live here

Get it as well...

Little comments

And they are not even digs 
Anyway

But that is the history that there is. (2007UK04)

This was described as an 'undercurrent of anti-English feeling in certain places... always in an abstract way' (2004UK01) by a Dublin-based male, and as 'resentment' by a Dublin-based woman (2007UK02). For a woman living in Dublin, this had translated to actual hostility: she described being told to 'f-ing well go home' while at a public event in the city (2004UK05). This behaviour was often excused, as in the words of the Corkbased man:

I can understand sometimes

Why a lot of the Irish people

Don't like the British,

Collectively...

I can understand why they don't like Britain...

I have a lot of sympathy for them and the fighting Irish,

I would feel exactly the same as them. (2007UK03)

Yet, the same man described his surprise at the 'terrible' level of knowledge of Scotland in Ireland:

\author{
I think it is surprising \\ That they don't know anything about it at all. \\ They know Scotch whiskey \\ And they know haggis \\ And Glasgow and Edinburgh \\ But that is it. (2007UK03)
}

Antonsich has suggested that belonging needs to be theorised in two separate though connected ways. The first refers to politics of belonging: the 'discourses and practices of socio-spatial inclusion/exclusion at play' in a particular place (Antonsich, 2010, p. 649). In this regard, British migrants are perhaps the most privileged group of migrants in Ireland, at least in terms of how their political belonging is facilitated. The second is what he describes as 'place-belongingness', or feeling 'at home'. The stories British migrants told us highlighted that political belonging does not necessarily lead to a clear sense of being 'at home', and that the process of 'place-belongingness' occurs at scales that extend and intersect over unexpected places and times.

\title{
Irish anxieties
}

British migrants have been, for well over a century, the most significant migrant group in Ireland, even though that presence is itself contested. The destruction, either by force or through neglect, of the big houses of the Anglo-Irish in the period after independence is perhaps the most material expression of that contestation, but it surfaces from time to time in a variety of contexts. In his short story, 'Guests of the Nation', Frank O'Connor, in addition to capturing the moral dilemmas of war, also highlights the confused nature of the relationship between British and Irish people in Ireland (O'Connor, 1991/1931). In the story the Irish narrator, Bonaparte, is one of a number of people responsible for holding two English soldiers hostage. Over the days of their captivity the two soldiers, Belcher and Hawkins, and their captors become friends, in part because of the soldiers' willingness to become part of daily life. 'Hawkins made us look like fools', Bonaparte said, 'when he showed us he knew the country better than we did' (O'Connor, 1991/ 1931 , p. 342). Bonaparte was in awe of the soldiers' ability to assimilate. 'You could 
have planted that pair down anywhere from this to Claregalway', he said, 'and they'd have taken root there like a native weed. I never in my short experience saw two men take to the country like they did' (O'Connor, 1991/1931, p. 342). When the two soldiers were later executed - and the description of their killing is very powerful and very poignant Bonaparte says 'And anything that happened to me afterwards, I never felt the same about again' (O'Connor, 1991/1931, p. 353). This narrative of ambivalence, where the political becomes personal, encapsulates some of the anxieties around making visible the long history of British migration to Ireland.

Writer and cartographer Tim Robinson has mapped and narrated the landscapes of Connemara and the Aran Islands with a poetic sensibility, attuned to the sounds of the past and their echoes in contemporary Ireland. As a chronicler of life in the Irish west, the mythologised heartland of Irish identity, Robinson has few equals. Yet, a lifetime of commitment to recording and celebrating the Irish landscape did not protect him from attack at a public meeting about a proposal to build an airport in Roundstone Bog. Robinson describes the furore at the meeting generated by a letter to the Irish Times that described the proposal as an act of pure stupidity and vandalism:

Here we have, roared the politician, brandishing the newspaper, someone with an address in London saying that Connemara men are vandals! - and he continued with such rage against this Englishman, as he insisted on calling him, that one of the Airport Group's more physicalist supporters suddenly leaped out of their ranks at me with fist clenched, roaring, 'And here's another... Englishman we should throw out!' (Robinson, 2001, p. 188)

Robinson describes with glee how he and other opponents of the airport proposal used the comment to gain the moral high ground at the meeting. However, he was clearly shocked by the incident, the first time a comment of the sort had been made to him in twenty years of living in Ireland. For Robinson, the fact that he had chosen to live and work in Ireland made it his home, but that choice was not validated in an angry exchange at a heated meeting. Instead, Robinson's 'otherness' became the issue, an 'otherness' based on an essentialist understanding of national identity in the context of a long colonial history. This experience was also recounted by the woman living in Dublin who told us 'I have never in my whole life felt that I was ostracised or in a minority, I never had that, and then when I came here a lot of people treat me differently' (2004UK05).

The overt and covert hostility displayed in these instances has a resonance for understanding the presence of British migrants in Ireland. In a variety of academic contexts, from literary theory to historical geography, the relationship between Britain and Ireland is explained and analysed using a postcolonial framework. There is no single practice or sets of ideas that defines postcolonialism (Young, 2003, p. 7). In the context of Ireland, therefore, postcolonial theory has been used in a variety of ways: to reframe the relationship between Ireland and Britain, to address the conflict in Northern Ireland, to interrogate the legacies of colonialism in contemporary Irish society, and to draw connections between the Irish situation and those of other colonies, particularly within the British Empire (see, for example, Carroll \& King, 2003; Cleary, 2002, 2006; Kiberd, 1995). Ireland, therefore, represents an exception to the claim that postcolonial theory is 'rarely used to study to reality of contemporary Europe' (Ponzanesi \& Blaagaard, 2011, p. 4). In Ireland, as elsewhere, a postcolonial approach is sometimes used to aid 'the recovery of those hidden spaces occupied, and invested with their own meaning, by the colonial underclass' (Crush, 1994, pp. 336-337). There is a political urgency in this act of 
recovery; a recognition of the silencing and marginalising tendencies of colonial power. But postcolonial theory is not only used in academic debates. When allied with exclusive forms of nationalism - as in the story Tim Robinson recounts - it becomes a powerful political tool: a way of deflecting attention from present wrongs to past injustices. Frantz Fanon warned against this, describing how, on independence, the native bourgeoisie 'violently attacks colonial personalities: barristers, traders, landed proprietors, doctors and higher civil servants. It will fight to the bitter end against these people "who insult our dignity as a nation"' (Fanon, 1963, p. 155). Fanon's alternative postcolonial analysis points to the ways in which the newly independent state repeats the patterns of the past, creating its own hidden spaces and imposing its own silences.

It is possible to argue that, to some extent, British migrants in Ireland inhabit the hidden spaces of the postcolonial era. In this context, their everyday geographies of belonging are affected by the political exploitation of anti-colonial and nationalist discourses. This point was brought home in an interview with a man from the north of England who had moved to Ireland because he had fallen in love with an Irish woman. His mother was Irish but, though he spent some summers in Ireland as a child, his was not a staunchly Irish upbringing. For two hours, he spoke very movingly about his life in Ireland - difficulties at work, dealing with children who were ill, struggles with money, and missing his family in England. Towards the end of the interview, he made some observations about living in Ireland, and the extent to which his sense of 'placebelongingness' was affected by colonialism and its aftermath:

I did sense

And I still do sense

To a certain degree

When I go out

On a social night into the city

That being from England is a problem.

I try to keep lower profile

As much as possible

Because I am aware of the history

Of why those feelings are there

I would prefer not to be in the situation

Where even you know unwittingly

I would be antagonizing the fact

When I am aware

That the problem could exist.

I appreciate why people think

The way they do

And I also understand

A little bit

About the way Irish history has gone

Even from the British leaving

And the civil war

And I know there there is

Still

A lot

Of the civil war type attitudes.

These words and experiences represent the grounded effects of postcolonial nationalist discourses on people who chose to make Ireland their home; as well as the political implications of the words of Ruttledge in That They May Face the Rising Sun who says, 
of his home in rural Ireland, 'It is where we live, a place like any other' (McGahern, 2002, p. 286).

\section{Conclusion}

British migrants to Ireland occupy an uneasy position. On the one hand, their presence is so imbricated in colonialist practices and discourses as to question the politics of making British migrants visible. On the other hand, the lack of attention to British migrants means that the heterogeneity of British migration, and indeed British identity, is masked. This obscures the possibility of alliances that cross national or ethnic boundaries, or of challenging exclusive conceptualisations of Irish identity that rely on blood ties or that exclude the returning migrant. The experiences of Irish migrants in Britain may offer some insight into why it is important to consider British people in Ireland as migrants. The relative invisibility of the Irish in official statistics (see Dunne, 2003; Mac an Ghaill, 2000; Walter, Gray, Dowling \& Morgan, 2002) meant that specific issues that affected Irish nationals in Britain - such as ill-health - could not be easily identified. Similarly, the recognition of audible minority status is also important: British nationals in Ireland are marked as different because of how they speak and sound, regardless of their sense of ethnic connection to Ireland (see Walter, 2008 on audibility among Irish nationals in Britain). Many of our research participants were highly aware that they sound different, and of the potentially negative associations of that difference. The expansion of the EU, and the increased possibilities for mobility that has created, means that intra-EU migration is increasingly characterised as 'internal' or 'circular' migration rather than 'international'. The assumption is that all EU migrants are 'at home' within the EU. Yet, the story of British migrants in Ireland demonstrates the importance of understanding the spatial and social relations that characterise the connections between particular places and particular people, and the implications of this for place-belongingness despite the apparent removal of formal barriers to belonging.

However, the reluctance to theorise British people as migrants in Ireland also has implications for others who have chosen to live in Ireland. Migrants in Ireland are generally understood as Nigerian asylum seekers, Polish builders, Filipina nurses, Brazilian meat factory workers - not (generally) white English speakers with a shared set of cultural references. In Ireland, as in the UK, there is a 'hierarchy of acceptability' (McDowell, 2009) where race and ethnicity - in all their relationality - provide a basis for assumptions of solidarity. This hierarchy leads to a tacit comparison between more acceptable and less acceptable migrants, with implications for those who are not favoured in terms of policy and in terms of everyday life. British migrants to Ireland may well be audible minorities, but their ability to 'pass' as not-quite-migrants is aided by a variety of practices that help to create the structural conditions for their integration into society in Ireland, such as recognition of qualifications and voting rights. They are less likely to be asked 'and when are you going home' than many other migrants to Ireland. In critical race studies, 'whiteness' is often described as unmarked and invisible. It may be possible to make a similar, albeit qualified, assertion about being British in Ireland.

That British nationals in Ireland are rarely acknowledged as migrants may well have emerged from the particular set of social and spatial relations that coalesced around colonialism. To an extent, British nationals may well be considered as 'internal migrants' - a situation that developed under colonialism and that persists today through the Common Travel Area and, increasingly, through greater levels of EU integration. 
However, the apparent reluctance to acknowledge British nationals in Ireland as migrants may well need to be understood through a different socio-spatial lens. Allan Pred, writing of the development of cultural racism in Sweden, highlighted the ways in which immigrants become the symbol of unease and anxiety at times of rapid change. As he commented, it is those who 'culturally and physically embody the newly unfamiliar', those who are 'less advanced' or 'unmodern', who are most likely to be scapegoats in the midst of unsettling changes (Pred, 2000, pp. 30-31). The crisis of identity in contemporary Ireland, marked by anxieties over the 'wrong' types of immigrants and, increasingly, the 'wrong' types of emigrants, is grounded through the bodies of the 'newly unfamiliar', or the migrant. The familiarity with Britain means that British people are not-quite-migrants, excused from carrying the burden of anxiety in a multicultural, rather than an anti-colonial, Ireland. Yet British migrants in Ireland live in a context that is marked by both colonialism and ethnic forms of nationalism, with implications for all migrants who have made Ireland their home. It is telling that McGahern again chose Ruttledge, the returned migrant from England, to sum this up: 'the way we perceive ourselves and how we are perceived are often very different' (2002, p. 3).

\section{Acknowledgements}

Dr Bettina Migge and I carried out the interviews discussed in this paper as part of a broader research project entitled 'Towards a dynamic approach to research on migration and integration'. I wish to acknowledge the Irish Council for Research in the Humanities and Social Sciences (IRCHSS) who generously funded the project. Earlier versions of this paper were presented at the Conference of Irish Geographers in Cork in 2009, and at the NUI Maynooth Department of Anthropology seminar series in 2010. The paper has benefited from the comments received in both places and from the perceptive insights of Mark Boyle, Bernard Mahon and two anonymous reviewers.

\section{Notes}

1. The use of the terms Britain, Ireland, UK, British, Irish, English and Scottish is complicated and requires explanation. Britain refers to England, Scotland and Wales, while the UK includes Britain and Northern Ireland. In general in this paper, I use the term British to identify people from England, Scotland and Wales. However, the Census in Ireland uses the term UK nationality rather than British nationality, so I use the term UK when directly referring to Census results. By Ireland/Irish, I generally mean the Republic of Ireland and its citizens. However, since the Republic of Ireland recognises people from Northern Ireland as Irish, and since many people from Northern Ireland identify as Irish, this is also a contested term.

2. In a recent paper, while acknowledging the increasingly blurred distinction between internal and international migration, King and Skeldon (2010, p. 1622) also recognise that the distinction 'needs to be maintained'.

3. Preliminary results from the 2011 Census show that Polish nationals are now the largest migrant group in Ireland. In April 2011, 122,585 Poles lived in Ireland, compared with 112,259 from the UK, the second-largest group (Central Statistics Office, 2012).

4. The $18 \%$ of our sample who identified as British corresponded to the $18.9 \%$ of the non-Irish national population who were identified as having UK nationality in the 2011 Census (Central Statistics Office, 2012).

5. Interviewees are identified by year of arrival (2004 or 2007), nationality (UK) and a numeric identifier.

6. See Note 5 .

7. To present longer quotes, I have used a technique described as ethnopoetry, which seeks to transform interview transcripts into poetry. See Aitken (2009, pp. 15-17) for a discussion of this method. 


\section{References}

Aitken, S. (2009). The awkward spaces of fathering. Farnham: Ashgate.

Antonsich, M. (2010). Searching for belonging - An analytical framework. Geography Compass, 4/6, 644-659. doi:10.1111/j.1749-8198.2009.00317.x

Beaverstock, J. V. (2002). Transnational elites in global cities: British expatriates in Singapore's financial district. Geoforum, 33(4), 525-538. doi:10.1016/S0016-7185(02)00036-2

Beaverstock, J. V. (2005). Transnational elites in the city: British highly-skilled inter-company transferees in New York city's financial district. Journal of Ethnic and Migration Studies, 31(2), 245-268. doi:10.1080/1369183042000339918

Benson, M. C. (2010). The context and trajectory of lifestyle migration: The case of the British residents of southwest France. European Societies, 12(1), 45-64. doi:10.1080/14616690802 592605

Carroll, C., \& King, P. (Eds.). (2003). Ireland and postcolonial theory. Cork: Cork University Press.

Central Statistics Office. (1952). Census 1946 Volume 3: Religion and birthplaces. Dublin: Stationery Office. Retrieved from http://www.cso.ie/census/census_1946_volume_3.htm

Central Statistics Office. (1993). Census 1986 Volume 8 - Usual residence, migration and birthplaces. Dublin: Stationery Office. Retrieved from http://www.cso.ie/census/Census_1986_ Results.htm

Central Statistics Office. (2003). Census 2002 Volume 4 - Usual residence, migration, birthplaces and nationalities. Dublin: Stationery Office. Retrieved from http://www.cso.ie/census/Vol4.htm

Central Statistics Office. (2007). Census 2006 Volume 4 - Usual residence, migration, birthplaces and nationalities. Dublin: Stationery Office. Retrieved from http://www.cso.ie/census/Census2006 Volume4.htm

Central Statistics Office. (2008). Census 2006: Non-Irish nationals living in Ireland. Dublin: Stationery Office.

Central Statistics Office. (2012). This is Ireland - Highlights from Census 2011, Part 1. Retrieved from http://www.cso.ie/en/media/csoie/census/documents/census $2011 \mathrm{pdr} / \mathrm{Census} \% 202011 \%$ 20Highlights\%20Part\%201\%20web\%2072dpi.pdf

Cleary, J. (2002). Literature, partition and the nation state: Ireland, Israel and Palestine. Cambridge: Cambridge University Press.

Cleary, J. (2006). Outrageous fortune: Capital and culture in modern Ireland. Dublin: Field Day.

Coles, A., \& Walsh, K. (2010). From 'Trucial State' to 'Postcolonial' city? The imaginative geographies of British expatriates in Dubai. Journal of Ethnic and Migration Studies, 36(8), 1317-1333. doi:10.1080/13691831003687733

Crush, J. (1994). Post-colonialism, de-colonization and geography. In A. Godlewska \& N. Smith (Eds.), Geography and empire (pp. 333-350). Oxford: Blackwell.

Dunne, C. (2003). An unconsidered people: The Irish in London. Dublin: New Island.

Ehrkamp, P., \& Leitner, H. (2006). Rethinking immigration and citizenship: New spaces of migrant transnationalism and belonging. Environment and Planning A, 38(9), 1591-1597. doi:10.1068/ a38349

Fanon, F. (1963). The wretched of the earth. New York: Grove Press.

Findlay, A., King, R., Stam, A., \& Ruiz-Gelices, E. (2006). Ever reluctant Europeans: The changing geographies of UK students studying and working abroad. European Urban and Regional Studies, 13(4), 291-318. doi:10.1177/0969776406065429

Fitzgerald, P., \& Lambkin, B. (2008). Migration in Irish History, 1607-2007. Hampshire and New York: Palgrave Macmillan.

Gilmartin, M., \& Migge, B. (2011). Working through a recession. Translocations: Migration and Social Change, 7(1). Retrieved from http://www.translocations.ie/current_issue.html. 2011.

Gilmartin, M., \& Migge, B. (2013). European migrants in Ireland: pathways to integration. European Urban and Regional Studies. doi:10.1177/0969776412474583

Gilmartin, M., \& Mills, G. (2008). Mapping migrants in Ireland. Translocations, 4(1), 21-34. Retrieved from http://www.translocations.ie/v04i01.html

Gilmartin, M., \& White, A. (2008). Revisiting contemporary Irish migration: New geographies of mobility and belonging. Irish Geography, 41(2), 143-149. doi:10.1080/007507708020 76919

Hegarty, S. (2007, July 7). Strangers from faraway shores are in our midst. Irish Times. 
Kiberd, D. (1995). Inventing Ireland: The literature of the modern nation. Cambridge, MA: Harvard University Press.

King, R., \& Ruiz-Gelices, E. (2003). International student migration and the European 'Year Abroad': Effects on European identity and subsequent migration behaviour. International Journal of Population Geography, 9(3), 229-252. doi:10.1002/ijpg.280

King, R., \& Skeldon, R. (2010). 'Mind the Gap' integrating approaches to internal and international migration. Journal of Ethnic and Migration Studies, 36(10), 1619-1646. doi:10.1080/1369183X. 2010.489380

King, R., Warnes, A. M., Warnes, T., \& Williams, A. M. (2000). Sunset lives: British retirement migration to the mediterranean. Oxford: Berg.

Leonard, P. (2010). Work, identity and change? Post/colonial encounters in Hong Kong. Journal of Ethnic and Migration Studies, 36(8), 1247-1263. doi:10.1080/13691831003687691

Mac an Ghaill, M. (2000). The Irish in Britain: The invisibility of ethnicity and anti-Irish racism. Journal of Ethnic and Migration Studies, 26(1), 137-147. doi:10.1080/136918300115697

McDowell, L. (2009). Old and new European economic migrants: Whiteness and managed migration policies. Journal of Ethnic and Migration Studies, 35(1), 19-36. doi:10.1080/ 13691830802488988

McGahern, J. (2002). That they may face the rising sun. London: Faber and Faber.

McIntosh, I., Sim, D., \& Robertson, D. (2004). 'It's as if you're some alien...' Exploring AntiEnglish Attitudes in Scotland. Sociological Research Online, 9(2). Retrieved from http://www. socresonline.org.uk/9/2/mcintosh.html doi:10.5153/sro.922

Merrill, H. (2006). An alliance of women: Immigration and the politics of race. Minneapolis: University of Minnesota Press.

Migge, B., \& Gilmartin, M. (2011). Migrants and healthcare: Investigating patient mobility among migrants in Ireland. Health and Place, 17(5), 1144-1149. doi:10.1016/j.healthplace.2011.05.002

Migge, B., \& Gilmartin, M. (2013). Unbounding migration studies: The intersections of language, space and time. In M. Gilmartin \& A. White (Eds.), Migrations: Ireland in a Global World (pp. 199-212). Manchester: Manchester University Press.

Nash, C. (2008). Of Irish descent: Origin stories, genealogy, and the politics of belonging. New York: Syracuse University Press.

National Archives of Ireland. (n.d.) Ireland in the early 20th century: Dublin - emigration and migration. Retrieved from http:/www.census.nationalarchives.ie/exhibition/dublin/emigration migration.html

O'Connor, F. (1991/1931). Guests of the Nation. In W. Trevor (Ed.), The Oxford book of short stories (pp. 342-353). Oxford: Oxford University Press.

Oliver, C. (2008). Retirement migration: Paradoxes of aging. New York: Routledge.

Oliver, C., \& O'Reilly, K. (2010). A Bourdieusian analysis of class and migration: Habitus and the individualizing process. Sociology, 44(1), 49-66. doi:10.1177/0038038509351627

O'Reilly, K. (2000). The British on the Costa Del Sol. London: Routledge.

Phillips, J., \& Potter, R. B. (2009). Quality of life issues and second-generation migration: The case of 'Bajan-Brit Returnees'. Population Space and Place, 15(3), 239-251. doi:10.1002/psp.507

Ponzanesi, S., \& Blaagaard, B. B. (2011). In the name of Europe. Social Identities, 17(1), 1-10. doi:10.1080/13504630.2011.531901

Potter, R. B., \& Phillips, J. (2009). Bajan-Brit second-generation return and migration: '...where am I supposed to be - in mid-air'?! In D. Conway \& R. B. Potter (Eds.), Return migration of the next generations: 21st century transnational mobility (pp. 79-99). Farnham and Burlington: Ashgate.

Pred, A. (2000). Even in Sweden: Racisms, racialized spaces and the popular geographic imagination. Berkeley, CA: University of California Press.

Ralph, D., \& Staeheli, L. A. (2011). Home and migration: Mobilities, belongings and identities. Geography Compass, 5(7), 517-530. doi:10.1111/j.1749-8198.2011.00434.x

Ravenstein, E. G. (1885). The laws of migration. Journal of the Statistical Society of London, 48(2), 169-235. doi:10.2307/2979181

Robinson, T. (2001). My time in space. Dublin: Lilliput Press.

Ryan, B. (2001). The common travel area between Britain and Ireland. Modern Law Review, 64(6), 831-854. doi:10.1111/1468-2230.00356 
Scott, S. (2006). The social morphology of skilled migration: The case of the British middle class in Paris. Journal of Ethnic and Migration Studies, 32(7), 1105-1129. doi:10.1080/ 13691830600821802

Sriskandarajah, D., \& Drew, C. (2006). Brits abroad: Mapping the scale and nature of British emigration. London: Institute for Public Policy Research.

Tolia-Kelly, D. P. (2004). Materializing post-colonial geographies: Examining the textural landscapes of migration in the South Asian home. Geoforum, 35(6), 675-688. doi:10.1016/j. geoforum.2004.02.006

Tolia-Kelly, D. P. (2006). Mobility/stability: British Asian cultures of 'landscape and Englishness'. Environment and Planning A, 38(2), 341-358. doi:10.1068/a37276

Walter, B. (2008). Voices in other ears: 'accents' and identities of the first- and second-generation Irish in England. In G. Rings \& A. Ife (Eds.), Neocolonial mentalities in Europe (pp. 174-182). Cambridge: Cambridge Scholars Press.

Walter, B., Gray, B., Dowling, L. A., \& Morgan, S. (2002). A study of the existing sources of information and analysis about Irish emigrants and Irish communities abroad. Dublin: Department of Foreign Affairs.

White, A., \& Gilmartin, M. (2008). Critical geographies of citizenship and belonging in Ireland. Women's Studies International Forum, 31(5), 390-399. doi:10.1016/j.wsif.2008.08.004

Yeoh, B. S. A., \& Willis, K. (2005). Singaporean and British transmigrants in China and the cultural politics of 'contact zones'. Journal of Ethnic and Migration Studies, 31(2), 269-285. doi:10.1080/1369183042000339927

Young, R. J. C. (2003). Postcolonialism: A very short introduction. Oxford: Oxford University Press. 